\title{
Using Service Learning As A Method Of Transferring Health Knowledge
}

Lana Zinger, City University of New York, USA

Alicia Sinclair, City University of New York, USA

\begin{abstract}
High school students enrolled in a College Now health education class were taught the importance of regular calcium consumption and then were trained on how to act as peer educators to disseminate the calcium information to their peers. This program empowered students through service learning to choose more dairy in their daily diet. Service learning is defined as education in action where students serve their communities by offering their knowledge, skills and time. As a result of this project, students reported success in applying the knowledge and skills taught by peer educators which helped students translate nutrition education into peer education.
\end{abstract}

Keywords: Service Learning, Health, Wellness

\section{INTRODUCTION}

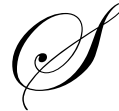

ervice learning integrates academic learning and relevant community service with classroom instruction, focusing on critical, reflective thinking and personal civic responsibility. Although definitions of service learning may differ slightly, the hallmarks of service learning are applied "real" projects or work that provide a beneficial service to organizations and/or individuals outside of the classroom and reinforce course-related skills and content. This project helped students translate nutrition education into peer education.

Service: Students serve their communities by offering their knowledge, skills and time.

Learning: Students get to know their communities, develop new skills and integrate knowledge of course materials into an authentic setting.

The City University of New York (CUNY) has developed a program entitled, College Now. College Now is a college preparatory program for high school students. More specifically, the program offers foundation courses to help students improve their basic skills within various disciplines to better prepare students for the challenges of college life.

For this program, two College Now Foundation Courses were offered in health education and taught by the principal investigators. As part of each course, students were educated on the importance of regular dairy consumption. The course instructors trained volunteer students to be peer educators within their own high school. Our overall goal was to educate and train peer educators to promote dairy consumption in a high school setting.

\section{BACKGROUND/LITERATURE REVIEW}

Review of service learning literature from a health and nutrition education context indicates that service learning pedagogy helps students become better advocates of nutrition and health awareness outside of the classroom.

A study by Litke (2002) on the outcomes of service learning found that both higher an lower performing students clearly believed that the course had an impact on personal growth. Also significant was the students' abilities to apply the knowledge and skills they learned from one setting to another. 
Palmer (1997) reported that real learning occurs when the course content and the experiences of the students intersect. Service learning as part of a course provides students with real world experiences that enhance course learning objectives.

In 2002, Moley et al, reported that students who participated in service learning showed expected changes in civic attitudes and an increase in self-rating in regards to their skills for community engagement. They also reported that service learning gave students opportunities to develop social and problem solving skills including communication and conflict resolution.

In 1998, Kezar wrote that, "in the broadest sense, service learning is a form of active, experiential learning that utilizes service in order to ground the learning process".

This paper demonstrates how one program used service learning pedagogy to teach high school students how to explain the importance of calcium consumption to their peers within their high school community. What was significant in this project was students' abilities to transfer the knowledge learned from the College Now class to their community of peers.

\section{METHODS/STRATEGIES/INTERVENTION APPLICATIONS}

Educating adolescents regarding the benefits of dairy consumption can be enhanced by developing a curriculum which includes training peer educators (who are students in the high school) to promote the consumption of dairy. Education in the consumption of dairy products will ensure that high school graduates are knowledgeable about dairy products as well as expose them to potential careers in nutrition and dietetics.

Peer educators selected from the College Now courses educated their peers in the high school to provide and encourage dairy use.

Peer educators did the following:

- $\quad$ Explained the benefits of consuming dairy on a daily basis.

- Disseminated health information regarding importance of calcium consumption.

- $\quad$ Surveyed the student population to assess their current dairy understanding and consumption.

- $\quad$ Designed individualized eating plans to include 3 daily servings of dairy.

Our student population was urban high school students between the ages of 15-18.

The program reached approximately 200 students.

A dairy foods curriculum packet and inservice training were provided for peer educators chosen from the College Now courses. A variety of dairy food information was made available to all students in the lunchroom with the goal of increasing awareness, empowering students with knowledge, and advocating for students to choose healthy dairy products.

The inservice training included the following:

- $\quad$ Building strong bones is a lot like building a healthy balance in your "calcium bank account." Bones are living tissue and constantly in a state of turnover, making calcium deposits and withdrawals daily.

- $\quad$ Calcium Goals

- $\quad$ How much calcium do you need?

- How does calcium help athletic performance and weight maintenance?

- $\quad$ Reading food labels and looking for foods and beverages with the highest calcium requirements

- $\quad$ How to get 3-a-day

- $\quad$ Look for the 3-A-Day logo on packages and of milk, cheese and yogurt

- $\quad$ Eat your favorite flavors of great-tasting milk, snackable cheeses and portable yogurt.

- $\quad$ Take a mid-day snack of milk, cheese and/or yogurt everyday to tally daily dairy servings. 
Students were also taught appropriate serving sizes and the calcium content of specific foods. For example:

\section{Sources}

Milk, low-fat or non-fat, 1 cup

Fruit yogurt, low-fat, 1 cup

Cheddar cheese, low-fat, 2 oz.

\section{Calcium Content}

\section{$301 \mathrm{mg}$}

$372 \mathrm{mg}$

$236 \mathrm{mg}$

Students were also taught how to role play with their peers on how to overcome common barriers to consuming dairy products. For example:

Barrier: "I don't like milk"

Strategy: Peer educators will help students select other forms of dairy; flavored milk, yogurt cheese, pudding, frozen yogurts.

Barrier: "I'm lactose intolerant"

Strategy: Peer educators will educate students about lactose intolerance and the selection of dairy foods that are lower in lactose.

Barrier: "Milk's not cold enough"

Strategy: Test temperature of dairy products with calibrated thermometer and inform staff when temperature of 41 degrees or lower is not reached. Discuss the feasibility of purchasing dairy coolers with Food Service manager.

\section{DISCUSSION}

This program empowered students through peer education to choose more dairy during their lunch hour and at other times. Peer educators served as role models to encourage dairy consumption by stressing that dairy would help increase athletic performance, control weight and decrease future risks of developing osteoporosis by helping students reach their peak bone mass.

National studies suggest that students in effective serving learning courses improve academically, increase attendance in class, and develop personal and social responsibility. The use of service learning in the College Now program helped all students involved to better understand the role calcium plays in their overall health.

\section{Challenges and barriers to using service learning}

While we found service learning to have many benefits, there were also some challenges and barriers that we encountered, such as:

1. Time required of students outside of class. In the future, we would use class time versus student free time.

2. Having peer educators be taken seriously by their fellow classmates.

3. Getting other faculty members in the school setting on board with this program. In the future, we would recruit more high school faculty to participate.

\section{Overall Impact}

Students reported that recipients of this service learning project had higher interest in personal health and nutrition. It was also reported that recipients were interested in pursuing possible health and nutrition career pathways by signing up for continuing education classes at QCC.

In the classroom, faculty members reported improved camaraderie among students and among faculty members involved in this project. Faculty noticed student attentiveness while in class was improved because students were more engaged as witnessed by higher quality questions, increased participation and overall greater 
interest in the subject matter. This project could potentially contribute to healthier schools and communities and better prepared students who possess the skills necessary to teach nutrition and health.

Through the process of setting up and facilitating this service learning project, QCC faculty members and students have an increasing presence within the community. For example, students reported that recipients of this service learning project had higher interest in personal health and nutrition. It was also reported that recipients were interested in pursuing possible health and nutrition career pathways by signing up for continuing education classes at QCC.

In the classroom, faculty members reported improved camaraderie among students and among faculty members involved in this project. Faculty noticed student attentiveness while in class was improved because students were more engaged as witnessed by higher quality questions, increased participation and overall greater interest in the subject matter. This project could potentially contribute to healthier schools and communities and better prepared students who possess the skills necessary to teach nutrition and health.

\section{Recommendations} the process.

Several things are critical for service learning success and should be addressed by practitioners throughout

\section{- $\quad$ Community Needs}

Service-learning must address genuine needs that are important to the community being served.

- $\quad$ Tailor to Course Objectives

In order to differentiate service-learning from regular community service work, educators must carefully tie projects to specific course objectives.

- $\quad$ Student Response

Reflection activities, such as a reflection journal, can be used to assess where students are in the learning process, provide opportunities for them to voice concerns and share feelings, and evaluate the project.

- $\quad$ Partnerships

Service-learning builds partnerships between students and their community. Partnerships can be limited to those being served or extended to include businesses, community-based organizations, social service agencies, and other groups that share the project's goals.

The following recommendations proved useful when implementing this service learning project:

- $\quad$ Students' grades are based on the demonstration of learning and meeting course objectives.

- The syllabus should include the rationale for incorporating community service into the course as well as specific student expectations.

- $\quad$ Build and foster relationships with the broader community

- Develop assignments that enable students to demonstrate what they learned from the community experience.

\section{AUTHOR INFORMATION}

Dr. Lana Zinger is a Registered Dietitian, Exercise Physiologist, and Associate Professor of Health based in New York City

Dr. Alicia Sinclair is a Certified Health Education Specialist with a specialization in nutrition and weight management. She is currently an Assistant Professor of Health based in New York City. 


\section{REFERENCES}

1. The International Partnership for Service Learning and Leadership. IPSL Declaration of Principles. 2006

2. The National Service Learning Clearinghouse Web site. http://www.servicelearning.org/welcome.

3. Making and impact on out-of-school time: A guide for corporation for national service programs engaged in after school, summer, and weekend activities for young people. Wellesley, MA: National Institute on Out-of-School Time at Wellesley College Center for Research on Women. 2000.

4. Kezar, A.J. (1998). Exploring new avenues for leading community colleges: the paradox of participatory models. Community College Review. 25(4). 75-87.

5. Litke, RA. Do all students "get it"?: Comparing students' reflections to course performance. Mich J Community Service Learning. 2002;8(2):27-34.

6. Moley,B.E., MeFarland,M., Miron, D., et al. Changes in college students' attitudes and intentions for civic involvement as a function of service learning experiences. Mich J Community Service Learning. 2002;9(1):44-51.

7. Palmer,P. The courage to teach: Exploring the inner landscape of a teacher's life. San Francisco: JosseyBass; 1997. 
NOTES 